\title{
IgMk paraprotein from gammopathy patient can bind to cardiolipin and interfere with coagulation assay: a case report
}

\author{
Xin-yao $\mathrm{Wu}^{1+}{ }^{1+}$ Yu-feng Yin ${ }^{1+}$, Jia-lin Teng ${ }^{1}$, Li-wei Zhang ${ }^{2}$ and Cheng-de Yang ${ }^{1 *}$
}

\begin{abstract}
Background: The monoclonal gammopathies are a group of plasma-cell proliferative disorders characterized by the secretion of monoclonal immunoglobulin (M protein or paraprotein). Some rare cases have revealed the specific affinity of paraprotein as autoantibody. Here we report a patient with monoclonal gammopathy of undetermined significance (MGUS) accompanied by a remarkable increase of anticardiolipin antibody (aCL) and an extensively decreased coagulation factor activity, however, without any clinical signs of antiphospholipid syndrome (APS) and bleeding.
\end{abstract}

Results: Our further investigation indicated that lgMk paraprotein of this patient possessed an antibody activity against phospholipids so as to bind to cardiolipin and interfere with coagulation assay in vitro.

Conclusions: This case might be indicative that an abnormality of coagulation tests, disturbed by lgMk paraprotein, does not predict a risk of bleeding in this patient.

Key words: Paraprotein, Monoclonal Gammopathy, Antibody, Phospholipid, Coagulation

\section{Background}

The monoclonal gammopathies, including monoclonal gammopathy of undetermined significance (MGUS) and multiple myeloma, are a group of plasma-cell proliferative disorders characterized by the secretion of monoclonal immunoglobulin [1]. MGUS denotes a preneoplastic entity that can develop into multiple myeloma or other lymphoproliferative disorders including macroglobulinemia or primary amyloidosis [2]. The incidence of MGUS, in a progression risk of $1 \%$ per year, is approximately 1 to $3.4 \%$ in the general population from 50 to 70 years old $[2,3]$.

Unlike CRAB features (hypercalcaemia, renal failure, anaemia, and bone lesions) of multiple myeloma, systemic manifestations presented in MGUS are rare and

\footnotetext{
* Correspondence: yangchengde@sina.com

${ }^{\dagger}$ Equal contributors

'Department of Rheumatology and Immunology, Ruijin Hospital, Shanghai Jiaotong University School of Medicine, No. 197 Ruijin Second Road, Huangpu District, Shanghai 200025, China

Full list of author information is available at the end of the article
}

extremely varied. However, several reports described that MGUS patients had both thrombolytic and hemorrhagic complications including deep venous thrombosis, acquired von Willebrand disease, prothrombotic abnormalities and acquired hemophilia [4-6]. Previous study suggested that these disorders in MGUS may be due to the antibody activity of the particular monoclonal immunoglobulin [6]. The specific affinity of paraprotein for thrombin or platelet glycoprotein IIIa was previously reported in two cases with severe bleeding disorders $[7,8]$. Here we described a MGUS patient with significantly increased level of anticardiolipin antibody (aCL) and decreased levels of coagulation factor activity, however, without any clinical manifestations of antiphospholipid syndrome (APS) and bleeding. We demonstrate here that the high positivity of aCL and reduced activity of coagulation factors might be the result of a specific immunologic reaction of $\operatorname{IgM\kappa }$ paraprotein with phospholipids. 


\section{Case report}

A 63-year-old man presented to our hospital in January 2016, with chronic watery diarrhea lasting for more than 6 months, three to five times per day, without any visible traces of blood. He reported no abdominal pain, tenesmus, fever, bone pain or suspicious manifestations of bleeding. He suffered from diabetes mellitus for more than 10 years with a good self-blood glucose monitoring and no family pedigree was reported. Physical examination on admission revealed malnutrition and mild anemia, with no lymphadenopathy or hepatosplenomegaly. Incomplete intestinal obstruction was showed by abdominal CT scan 2 months before, however, not detected by gastroscopy and colonoscopy at admission.

Complete blood count showed a hemoglobin level of $80 \mathrm{~g} / \mathrm{L}$, a platelet count of $256 \times 10^{9} / \mathrm{L}$, and a white blood cell count of $4.89 \times 10^{9} / \mathrm{L}$ with normal differentiation. The patient had a decreased level of serum total protein $(45 \mathrm{~g} / \mathrm{L}$; normal range $60-83 \mathrm{~g} / \mathrm{L})$, albumin (24 g/L; 35-55 g/L), IgG (503 mg/dl; 751-1560 mg/dl) and a significantly raised IgM $(984 \mathrm{mg} / \mathrm{dl} ; 46-304 \mathrm{mg} /$ dl). Serum levels of IgA and IgE were in the normal range. The enzyme-linked immunosorbent assay (ELISA) (EUROIMMUN, Lübeck, Germany) was used to detect the serum level of Antiphospholipid antibody (APLA) including $\mathrm{aCL}$ and anti- $\beta 2 \mathrm{GP} 1$ antibodies. Serum level of aCL (IgM) was significantly elevated up to $69.8 \mathrm{MPL} /$ $\mathrm{ml}$ (normal range $<12 \mathrm{MPL} / \mathrm{ml}$ ) while serum aCL (IgG) $(<2 \mathrm{GPL} / \mathrm{ml} ;<12 \mathrm{GPL} / \mathrm{ml})$ and anti- $\beta 2 \mathrm{GP} 1$ antibodies $(11.2 \mathrm{RU} / \mathrm{ml} ;<20.0 \mathrm{RU} / \mathrm{ml})$ were within normal limits. In our laboratory, the reference range was established as titers equal or exceeding $99 \%$ of healthy pregnant and non-pregnant woman for aCL (IgM) (12 MPL/ml), aCL (IgG) $(12 \mathrm{GPL} / \mathrm{ml})$ and anti- $\beta 2 \mathrm{GP} 1$ antibodies (20.0 RU/ $\mathrm{ml}$ ) respectively. Lupus anticoagulant was 2.13 ( $>2$ was defined as strong activity). The serum level of $M$ paraprotein was $2.7 \mathrm{~g} / \mathrm{L}$ and was determined as IgMк type in immunofixation electrophoresis. More importantly, he had an extremely prolonged activated partial thromboplastin time (APTT) (114.7 s; 27.2-41.0 s), slightly increased prothrombin time (PT) $(23.0 \mathrm{~s} ; 10.0-16.0 \mathrm{~s})$ and D-dimer $(1.04 \mathrm{mg} / \mathrm{L} ;<0.55 \mathrm{mg} / \mathrm{L})$ (Table 1$)$, together with a remarkable deficiency of all coagulation factors activity (Table 2).

\section{Results}

We hypothesized that the IgM $\mathrm{K}$ paraprotein of this patient possessed a specific affinity for phospholipid, which served as anticardiolipin antibodies and disturb coagulation detection via binding to platelet phospholipid substitute in vitro. Therefore, we conducted a series of in vitro experiments to verify our hypothesis. The serum IgMk paraprotein of this patient was purified using HiTrap IgM Purification HP and HiTrap
Table 1 Demographic and blood parameters of the patient

\begin{tabular}{|c|c|c|}
\hline Characteristics & Value & Reference (unit) \\
\hline Age & 63 & year \\
\hline Hemoglobin & 80 & $g / L$ \\
\hline Platelet count & 256 & $85-303 \times 10^{9} / L$ \\
\hline White blood cell count & 4.89 & $3.97-9.15 \times 10^{9} / \mathrm{L}$ \\
\hline Serum total protein & 45 & $60-83 \mathrm{~g} / \mathrm{L}$ \\
\hline Albumin & 24 & $35-55 \mathrm{~g} / \mathrm{L}$ \\
\hline $\lg G$ & 503 & $751-1560 \mathrm{mg} / \mathrm{dl}$ \\
\hline $\lg M$ & 984 & $46-304 \mathrm{mg} / \mathrm{dl}$ \\
\hline Anticardiolipin antibody (IgM) & 69.8 & $<12 \mathrm{MPL} / \mathrm{ml}$ \\
\hline Anticardiolipin antibody (lgG) & $<2$ & $<12 \mathrm{GPL} / \mathrm{ml}$ \\
\hline Anti- $\beta 2 \mathrm{GP1}$ antibody & 11.2 & $<20.0 \mathrm{RU} / \mathrm{ml}$ \\
\hline Lupus anticoagulant & 2.13 & $<1.2$ \\
\hline M paraprotein (lgMk) & 2.7 & $g / L$ \\
\hline Activated partial thromboplastin time & 114.7 & $27.2-41.0 \mathrm{~s}$ \\
\hline Prothrombin time & 23.0 & $10.0-16.0 \mathrm{~s}$ \\
\hline D-dimer & 1.04 & $<0.55 \mathrm{mg} / \mathrm{L}$ \\
\hline \multicolumn{3}{|l|}{ Bone marrow (FCM) } \\
\hline $\mathrm{CD}_{19}^{+}$cell & 11.1 & $\%$ \\
\hline $\mathrm{CD}_{19}{ }^{+} \mathrm{CD} 20^{+}$cell & 98.2 & $\%$ \\
\hline $\mathrm{CD} 19^{+} \mathrm{CD} 38^{+}$cell & 94.5 & $\%$ \\
\hline $\mathrm{CD}_{19} \mathrm{CD}^{+} 138^{+}$cell & $<0.1$ & $\%$ \\
\hline $\mathrm{CD}_{19}{ }^{+}$cyt-lgk ${ }^{+}$cell & 94.2 & $\%$ \\
\hline CD19 ${ }^{+}$cyt-lg $\lambda^{+}$cell & 4.4 & $\%$ \\
\hline
\end{tabular}

Abbreviations: FCM Flow Cytometry Method

Protein L columns (GE Healthcare, CA, USA) and the purity $(>95 \%)$ was verified by SPIFE Immunofixation electrophoresis (IFE) Kits (HELENA Laboratories, Beaumont, TX, USA). Then, the IgMk sample was prepared by adding the purified IgMк paraprotein to the normal control plasma and the final concentration was $1.72 \mathrm{~g} / \mathrm{L}$. Anticardiolipin antibody properties of IgMk paraprotein was evaluated using aforementioned Anti-Cardiolipin kit (EUROIMMUN, Lübeck, Germany), and the result demonstrated a strong positivity $(32.4 \mathrm{MPL} / \mathrm{ml})$. On the other hand, the anticardiolipin activity of the purified IgM collected from a patient with Waldenström's macroglobulinemia (WM), with a final concentration of $2.0 \mathrm{~g} / \mathrm{L}$ after addition to the normal control plasma, was only 1.47 $\mathrm{MPL} / \mathrm{ml}$.

Finally, we repeated the coagulation tests on IL coagulation systems (HemosIL, MA, USA), our results showed that there was a significantly decrease of coagulation factors activity (VIII, IX, XI, XII, II, V, VII, and X) in our IgMk sample, indicating the inhibiting effects of IgMk paraprotein on the assay of coagulation factors activity, the results were summarized in Table 2 . 
Table 2 Comparison of coagulation factor activity in patient plasma and purified lgMk paraprotein plus normal control plasma

\begin{tabular}{lccc}
\hline $\begin{array}{l}\text { Coagulation } \\
\text { factor }\end{array}$ & $\begin{array}{l}\text { NC } \\
\text { (\% of activity) }\end{array}$ & $\begin{array}{l}\text { Patient } \\
\text { (\% of activity) }\end{array}$ & $\begin{array}{l}\text { IgMk }+ \text { NC } \\
\text { (\% of activity) }\end{array}$ \\
\hline Factor VIII & 183.6 & 3.1 & 6.1 \\
Factor IX & 111.9 & 2.6 & 3.9 \\
Factor XI & 87.7 & 3.5 & 3.3 \\
Factor XII & 78.9 & 6.5 & 3.5 \\
Factor II & 102.5 & 15.0 & 20.5 \\
Factor V & 90.6 & 40.3 & 39.1 \\
Factor VII & 112.6 & 58.9 & 38.5 \\
Factor X & 98.4 & 20.2 & 25.3 \\
\hline
\end{tabular}

The reference of all coagulation factors: $50-150 \% ; \mathrm{NC}=$ normal control plasma; $\operatorname{lgM}+\mathrm{NC}=$ purified lgMk paraprotein plus normal control plasma

(final concentration of $\mathrm{lgMK} 1.72 \mathrm{~g} / \mathrm{L}$ )

After ruling out the diagnosis of multiple myeloma and other B-cell proliferative disorder based on the evaluation of bone marrow biopsy, a diagnosis of MGUS was finally established. The patient was administrated by Clostridium butyricum and Pancreatin for diarrhea. His diarrhea disappeared with the aid of aforementioned symptomatic therapy for 10 days, but the abnormality in coagulation tests and the elevated $M$ protein in electrophoresis of serum protein remained unchanged. In consideration of no further clinical manifestations, especially intestinal or hematological disorders, a regular follow-up was required for this patient.

\section{Discussion}

We present here a patient with positive aCL antibodies and significantly reduced coagulation factor activity. Our experiments demonstrated an antibody property of IgMk paraprotein that can bind to cardiolipin and interfere with assay of coagulation in this patient with MGUS. To explain the co-existence of positivity of aCL, hypocoagulability indicated by prolongation of APTT, the decrease in coagulation factors activity, and the absence of hemorrhagic disorders in clinical manifestation, we put forward a possible mechanism that the paraprotein might attack the phospholipid, a substitute of the platelet factor 3 which play an indispensable role in the common pathway of coagulation process in vivo [9]. Our results indicate that aCL positivity and the atypical coagulation detection might be a false positivity due to the specific antibody activity of IgMк paraprotein against the phospholipid substitute in vitro.

Paraprotein have been thought of having antibody properties against clotting factors in several reported case $[7,10,11]$. A patient with similar prolongation of APTT and abnormality of multiple coagulation factors was reported to have severe bleeding and monoclonal antithrombin antibody [7]. Another case of Waldenstroem's disease presented a high titer of monoclonal antiphospholipid antibodies, which did apparently not induce the clinical symptoms of antiphospholipid syndrome (APS) [10]. A third patient with IgM $\lambda$ paraprotein and prolongation of APTT and PT, despite absence of bleeding manifestations and specific coagulation factor inhibition [11]. Abovementioned cases shared both similarities and differences with our case. The mechanism of interaction between phospholipid and coagulation process as well as the production of monoclonal immunoglobulin remained complicated and unclear.

Besides specific affinity for autoantigens participated in coagulation process, antibody activities of monoclonal immunoglobulin reported in cases were highly varied, like IgM acting as anti-myelin-associated glycoprotein (MAG) antibodies in MGUS associated with peripheral neuropathy [12], IgM and IgG against transferrin in MGUS associated with transferrin-immune complex disease (TICD) [13] and IgG as antibodies against the CUB1-2 domains of ADAMTS13 in a MGUS patient associated with thrombotic thrombocytopenic purpura [14]. The existence of monoclonal immunoglobulin with specific affinity could also be found in multiple myeloma [15].

This is the first report of IgMk paraprotein as antibodies against phospholipids to bind to cardiolipin and interfere with coagulation assay. This case provide an explanation for the dissociation of aberrant laboratory examination and clinical manifestation. Coagulation detection does not always reflect the real coagulation status in vivo. Great attention should be paid to the choice of hemostatic therapy or anticoagulation therapy in patients with antiphospholipid antibodies and coagulation abnormalities.

\section{Abbreviations}

APTT: Activated partial thromboplastin time; MGUS: Monoclonal gammopathy of undetermined significance; PT: Prothrombin time

\section{Acknowledgements}

We express our gratitude to the patient for his participation. We acknowledge Hui Shi, Yue Sun, Hong-lei Liu, Xiao-bing Cheng, Jun-na Ye, Yu-tong Su and Guan-qun Xu. We appreciate the precious suggestions for revision in our study.

\section{Funding}

This study was supported by National Natural Science Foundation of China (81373211).

\section{Availability of data and materials}

Data sharing not applicable to this article as no datasets were generated or analysed during the current study.

\section{Authors' contributions}

XYW searched for literature and drafted the manuscript. YFY designed the experiment and analyzed data. JLT participated in data interpretation. LWZ provided the experiment materials. CDY provided analytical oversight and revised the manuscript. All authors have read and approved the final version to be published. 


\section{Competing interests}

The authors declare that they have no competing interests.

\section{Consent for publication}

Written consent from the patient to report individual data for publication was obtained.

\section{Ethics approval and consent to participate}

This study was approved by the Clinical Ethics Committee of Ruijin Hospital, Shanghai Jiaotong University School of Medicine.

\section{Publisher's Note}

Springer Nature remains neutral with regard to jurisdictional claims in published maps and institutional affiliations.

\section{Author details}

'Department of Rheumatology and Immunology, Ruijin Hospital, Shanghai Jiaotong University School of Medicine, No. 197 Ruijin Second Road, Huangpu District, Shanghai 200025, China. ${ }^{2}$ Department of Clinical Laboratory, Ruijin Hospital, Shanghai Jiaotong University School of Medicine, Shanghai 200025, China

Received: 15 December 2016 Accepted: 7 June 2017

Published online: 23 June 2017

\section{References}

1. International Myeloma Working G. Criteria for the classification of monoclonal gammopathies, multiple myeloma and related disorders: a report of the International Myeloma Working Group. Br J Haematol. 2003;121(5):749-57.

2. Kyle RA, Rajkumar SV. Monoclonal gammopathies of undetermined significance: a review. Immunol Rev. 2003;194:112-39.

3. Caers J, Vekemans M-C, Bries G, Beel K, Delrieu V, Deweweire A, Demuynck H, De Prijck B, De Samblanx H, Kentos A, et al. Diagnosis and follow-up of monoclonal gammopathies of undetermined significance; information for referring physicians. Ann Med. 2013;45(5-6):413-22.

4. Taher A, Abiad R, Uthman I. Coexistence of lupus anticoagulant and acquired haemophilia in a patient with monoclonal gammopathy of unknown significance. Lupus. 2003;12(11):854-6.

5. Sallah S, Husain A, Wan J, Vos P, Nguyen NP. The risk of venous thromboembolic disease in patients with monoclonal gammopathy of undetermined significance. Ann Oncol. 2004;15(10):1490-4.

6. Decaux O, Laurat E, Perlat A, Cazalets C, Jego P, Grosbois B. Systemic manifestations of monoclonal gammopathy. Eur J Intern Med. 2009;20(5):457-61.

7. Colwell NS, Tollefsen DM, Blinder MA. Identification of a monoclonal thrombin inhibitor associated with multiple myeloma and a severe bleeding disorder. Br J Haematol. 1997;97(1):219-26.

8. Diminno G, Coraggio F, Cerbone AM, Capitanio AM, Manzo C, Spina M, Scarpato P, Dattoli GM, Mattioli PL, Mancini M. A myeloma paraprotein with specificity for platelet glycoprotein Illa in a patient with a fatal bleeding disorder. J Clin Invest. 1986;77(1):157-64.

9. Spaet TH, Cintron J. Studies on Platelet Factor-3 Availability. Br J Haematol. 1965:11:269-75.

10. von Landenberg P, Scholmerich J, Andreesen R, Vogelhuber M, Lackner KJ. A case of Waldenstroem's disease with a monoclonal lgM antiphospholipid antibody. Rheumatol Int. 2002;22(3):129-31.

11. Thiagarajan P, Shapiro SS, De Marco L. Monoclonal immunoglobulin M lambda coagulation inhibitor with phospholipid specificity. Mechanism of a lupus anticoagulant. J Clin Invest. 1980;66(3):397-405.

12. Talamo G, Mir MA, Pandey MK, Sivik JK, Raheja D. IgM MGUS associated with anti-MAG neuropathy: a single institution experience. Ann Hematol. 2015;94(6):1011-6.

13. Forni GL, Pinto V, Musso M, Mori M, Girelli D, Caldarelli I, Borriello A, Ragione FD. Transferrin-immune complex disease: a potentially overlooked gammopathy mediated by IgM and IgG. Am J Hematol. 2013;88(12):1045-9.

14. Riksen NP, Luken BM, Klasen IS, Voorberg J, Crama N, van Deuren M. Antibodies against the CUB1-2 domains of ADAMTS13 in a patient with benign monoclonal gammopathy: no causal relationship. Haematologica. 2007;92(7):e74-6.

15. Konrad RJ, Kricka LJ, Goodman DB, Goldman J, Silberstein LE. Brief report: myeloma-associated paraprotein directed against the HIV-1 p24 antigen in an HIV-1-seropositive patient. N Engl J Med. 1993;328(25):1817-9.

\section{Submit your next manuscript to BioMed Central and we will help you at every step:}

- We accept pre-submission inquiries

- Our selector tool helps you to find the most relevant journal

- We provide round the clock customer support

- Convenient online submission

- Thorough peer review

- Inclusion in PubMed and all major indexing services

- Maximum visibility for your research

Submit your manuscript at www.biomedcentral.com/submit 